\title{
Comparison of the fat allocation patterns in female pine sawflies (Hymenoptera: Diprionidae)
}

\author{
ANNETTE HERZ* and WERNER HEITLAND \\ Lehrstuhl für Angewandte Zoologie, Forstwissenschaftliche Fakultät, Technische Universität München, Am Hochanger 13, D-85343 \\ Freising, Germany; e-mail: aherz@freenet.de
}

Key words. Diprionidae, pine defoliator, resource allocation, outbreak tendency, feeding behaviour, oviposition behaviour

\begin{abstract}
The allocation of fat resources to somatic and reproductive tissues was studied in females of five species of pine sawflies (Diprion pini (L.), Diprion similis (Htg.), Gilpinia frutetorum (F.), Gilpinia pallida (Klug), Neodiprion sertifer (Geoffroy); Hymenoptera, Diprionidae). The soma and eggs of newly emerged females were separated and then put in ether to extract and determine their fat content. The fat allocation patterns differed between species. The gregarious outbreak species $D$. pini and $N$. sertifer allocated most of the fat to their eggs, whereas the gregarious non-outbreak species, G. pallida, allocated most to its somatic tissues. No modification of these basic allocation patterns was observed with increasing total fat content. In contrast, the solitary nonoutbreak species, $D$. similis and $G$. frutetorum, invested equal amounts of fat in soma and eggs, and the proportion allocated to the egg load decreased as total fat content increased. That is, they invested additional resources in somatic tissues. Apparently, outbreak species tend to allocate more fat to reproductive tissues than non-outbreak species.
\end{abstract}

\section{INTRODUCTION}

There are around 13 species of European pine sawflies (Diprionidae) and some of them are important pests of pine forests (Larsson et al., 1993). The life histories of the different species appear to be similar: eggs are laid in pine needles, developing larvae feed on the needles, they pupate in cocoons and emerge as adults after a diapause. However, there are profound differences in the feeding behaviour of larvae as a consequence of particular oviposition strategies. Species with gregarious larvae lay their complete egg load more or less in one cluster (Escherich, 1942), whereas species with solitary living larvae distribute their eggs spatially (Pschorn-Walcher, 1982). The specific modes of oviposition should set particular demands for mobility and longevity of egg-laying females and be associated with a dissimilar investment of nutrient resources in reproduction and survival (Papaj, 2000). To test this hypothesis, we compared the resource allocation patterns of several pine sawflies exhibiting different oviposition strategies. In particular, we considered the investment of fat in eggs versus soma, as fat is used as an important source for oogenesis as well as of energy in insects (Beenakkers, 1969; Ellers, 1996; Wheeler, 1996). Potential constraints arising from different allocation patterns are discussed in relation to the particular life histories and outbreak tendencies of the species studied.

\section{MATERIALS AND METHODS}

\section{Origin of insects}

Five species of Diprionidae were studied. They exhibit different oviposition strategies and larval feeding behaviour. Moreover, they vary in their outbreak tendency (Table 1). The gregarious feeding Diprion pini (L.) and Neodiprion sertifer (Geoffroy) are severe pests showing frequent infestations, whereas outbreaks of the (semi-) solitary living Diprion similis (Htg.) and Gilpinia frutetorum (F.) are rare. The gregarious species Gilpinia pallida (Klug) occurs only sporadically at high densities, at least in Central Europe (Pschorn-Walcher, 1982). Females were obtained from continuous laboratory mass cultures (Herz, 1997). Laboratory stocks originated from field collected larvae and cocoons from different European countries (Table 1) and were reared under constant laboratory conditions $\left(22^{\circ} \mathrm{C}, 18 \mathrm{~L}: 6 \mathrm{D} \mathrm{h}\right)$ for several generations. However, it was not possible to rear $N$. sertifer continuously due to the diapause of the sawfly embryo inside the egg (Pschorn-Walcher, 1982) and the occurence of a highly virulent nucleopolyhedrosis. Consequently, young instars of $N$. sertifer were collected in the field, reared under laboratory conditions, and the resultant adult females were used in this study.

\section{Treatment of females}

Diprionid females are proovigenic and contain their entire supply of mature eggs when they emerge from the cocoon (Schedl, 1991). Therefore, females were killed directly after emergence by freezing at $-25^{\circ} \mathrm{C}$. The amount of fat was determined gravimetrically for individual females following the procedure described by Ellers (1996). Two cover slips $(18 \times 18$ $\mathrm{mm}$ ) were weighed, a female was put on one of them and its abdomen was cut open. After adding one drop of deionised water, the eggs were removed from the ovarioles, transferred individually to the second cover slip and counted. The cover slips plus insect parts were dried until of constant weight $\left(80^{\circ} \mathrm{C}\right.$, 6 days for all sawfly species) and the dry weight of the soma (cover slip 1) and the egg load (cover slip 2), respectively, was determined. Then $3 \mathrm{ml}$ of diethylether was added to each cover slip and the fat extracted for $24 \mathrm{~h}$ at room temperature. Then the diethylether was carefully changed and the extraction continued for another $24 \mathrm{~h}$. After this, the insect parts were dried for 6 days at $80^{\circ} \mathrm{C}$ and the dry weight determined again. The loss in weight corresponded to the amount of fat in soma and egg load, respectively. Preliminary investigations on $D$. pini, the largest of the species studied, were used to establish this procedure. Constant dry weight was achieved after 5 days. There were no differences in the fat content of whole bodies (abdomen open, but

\footnotetext{
* Corresponding author. Present address: Institute for Biological Control, Federal Biological Research Centre for Agriculture and Forestry, Heinrichstr. 243, D-64287 Darmstadt, Germany.
} 
TABLE 1. Life history traits, outbreak tendency and origin of the laboratory cultures of pine sawfly species.

\begin{tabular}{lcccc}
\hline & $\begin{array}{c}\text { Outbreak } \\
\text { tendency }\end{array}$ & $\begin{array}{c}\text { Distribution } \\
\text { of eggs }\end{array}$ & $\begin{array}{c}\text { Larval } \\
\text { feeding } \\
\text { behaviour }\end{array}$ & $\begin{array}{c}\text { Origin of } \\
\text { culture }\end{array}$ \\
\hline N. sertifer & High & $\begin{array}{c}\text { Single } \\
\text { cluster } \\
\text { D. pini }\end{array}$ & Gregarious & Germany \\
D. similis & $\begin{array}{c}\text { Single } \\
\text { cluster } \\
\text { diate }\end{array}$ & $\begin{array}{c}\text { Several } \\
\text { clusters }\end{array}$ & $\begin{array}{c}\text { Semi- } \\
\text { solitary }\end{array}$ & Finland \\
G. frutetorum & $\begin{array}{c}\text { Interme- } \\
\text { diate }\end{array}$ & Single eggs & Solitary & Germany/ \\
G. pallida & Low & $\begin{array}{c}\text { Several } \\
\text { clusters }\end{array}$ & Gregarious & Germany \\
& & & & \\
\hline
\end{tabular}

still containing all the eggs), extracted for $24 \mathrm{~h}, 48 \mathrm{~h}$ or $96 \mathrm{~h}$, so we chose $48 \mathrm{~h}$ as a sufficient period for fat extraction.

In addition, the average egg size of each species was estimated by measuring the lengths and middle widths of 10 eggs/female and 5 females/species. The shape of the eggs of the different species is similar ("banana"-like) and the volume (V) of an egg was calculated using $\mathrm{V}=\pi(\text { width } / 2)^{2}$ length.

\section{Evaluation of data}

The following variables were determined:

1. Number of eggs per female and average volume of eggs.

2.Total body weight (BW) [mg]: dry weight of soma + dry weight of egg load before fat extraction. BW was used as an estimate of body size.

3. Fat [mg]: absolute amount of fat in soma or egg load.

4. Fat content (Fat/[unit BW]): relative amount of fat in soma or egg load in relation to BW. Total fat/[unit BW] is the sum of these values.

5. Fat allocation: Proportion or percentage of total fat allocated to the egg load or soma, respectively.

The statistical analysis was performed using linear regression and ANOVA by adopting General Linearized Models. Proportions were arcsine-transformed where appropriate. Means were compared by $t$-tests on pairwise differences between parameter estimates in the General Linearized Model (Crawley, 1993).

\section{RESULTS}

The sawfly species studied differed in several somatic and reproductive traits (Table 2 ). The highest egg load was found in $D$. pini, which was also the largest of the species (as indicated by total $\mathrm{BW}$ ). G. pallida and $N$. sertifer were significantly smaller than the other species and had fewer eggs. However the eggs of $N$. sertifer were larger than those of the other sawflies (Table 2: column 5). The sawflies also varied significantly in their total fat content, with females of $G$. frutetorum accumulating the most fat (Table 2: column 6). The fat content (fat/unit [BW]) of the egg load was significantly different from that of the soma in the gregarious species $D$. pini, $N$. sertifer and $G$. pallida, whereas the (semi-)solitary species $D$. similis and $G$. frutetorum invested equal amounts of fat in eggs and soma (Table 2: column 7).

The allocation of fat to the eggs differed between species (Fig. 1, ANOVA: $F=24.53$, d.f. $=(4,207), P<0.01)$. In principle, three species groups can be distinguished: (1) the gregarious species $N$. sertifer and $D$. pini allocated most of their fat (about $60 \%$ ) to their eggs, (2) the solitary species $D$. similis and $G$. fru-

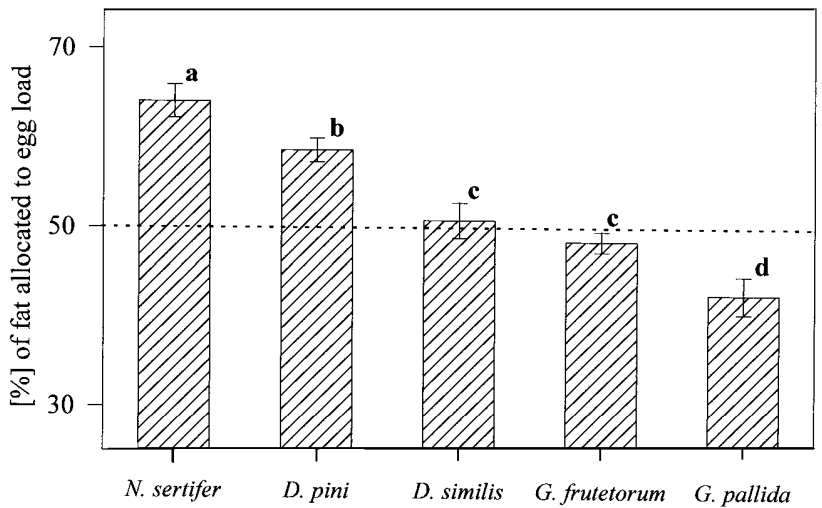

Fig. 1. Percentage of fat allocated to the egg load (mean \pm $\mathrm{SE}$ ) in females of five pine sawfly species. Significant differences between means are indicated by different letters $(P<$ $0.05, t$-tests on pairwise differences between parameter estimates in the General Linearized Model).

tetorum invested about half of their fat in their eggs and (3) the gregarious species, G. pallida, less than half of its fat (43\%).

Plasticity in the allocation of fat with increase in total fat was tested by the regression of the total fat content $(\mathrm{x}=$ total fat/[unit BW]) on fat allocation ( $y=$ proportion of fat allocated to eggs) in a particular species. The basic allocation pattern remained unchanged in the gregarious species. However, in the (semi-)solitary living $D$. similis and $G$. frutetorum the proportion in the egg load decreased with increasing fat content $(D$. similis: $y=-1.299 x+0.824, \mathrm{~F}=10.16,(1,23), P<0.005 ; G$. frutetorum: $y=-0.701 x+0.679, \mathrm{~F}=3.34,(1,51), P=0.072)$.

\section{DISCUSSION}

The results of this study confirm that pine sawfly species differ in their pattern of fat allocation to eggs and soma. However, there is no clear relationship between the allocation patterns and the dichotomy in sawfly oviposition. D. pini and $N$. sertifer are gregarious and lay their eggs in one large cluster (Pschorn-Walcher, 1982; Blümke \& Anderbrant, 1997). Survival of larvae increases with colony size (Lyons, 1962), probably because the feeding of the early instars is enhanced or large colonies are better able to defend themselves so reducing the mortality risk per capita (Heitland \& Pschorn-Walcher, 1993; Codella \& Raffa, 1995; Hunter, 2000). The data presented indicate that these sawfly species invested most of their fat in their egg load, producing more or larger eggs. D. pini had the highest number of eggs (especially in comparison to the nearly similar sized D. similis). $N$. sertifer had the least, but the largest eggs of all the species. In contrast to the other European sawflies, this species overwinters in the egg and presumably has to optimize its egg size in terms of energy reserves.

Distributing eggs singly or in several small clusters spatially can be seen as a risk-avoiding strategy, which is often associated with cryptic colouration and behaviour of solitary feeding larvae (Prop, 1960). These species, in contrast to egg-clustering species, are likely to spend more time travelling and ovipositing, which are energetically costly. The results of this study lend to this contention, as the (semi-)solitary species $G$. frutetorum and $D$. similis allocated comparatively more fat to soma than $D$. pini and $N$. sertifer. Moreover, with increasing fat content, both (semi-)solitary species increased their investment of fat in soma. In addition, in the laboratory the longevity of the solitary G. frutetorum (10 days) was greater than that of the gregarious $D$. pini (7 days) (Herz, unpublished data). 
TABLE 2. Average somatic and reproductive traits of newly emerged females of five pine sawfly species. Values are means \pm SD. $n$ : number of females examined per species, [u BW]: unit body weight. ${ }^{1}$ : Means followed by different letters are significantly different $\left(P<0.05\right.$, estimated by $t$-tests on pairwise differences between parameter estimates in the General Linearized Model). ${ }^{2}:$ Significant differences between the fat content of soma and egg load for a particular sawfly species at $P<0.001$ are indicated by ${ }^{* * *}$.

\begin{tabular}{lcccccc}
\hline Species & $n$ & $\begin{array}{c}\text { Total BW } \\
{[\mathrm{mg}]^{\mathbf{1}}}\end{array}$ & $\begin{array}{c}\mathrm{N} \\
\text { of eggs }^{1}\end{array}$ & $\begin{array}{c}\text { Volume of eggs } \\
{\left[\mathrm{mm}^{3}\right]^{1}}\end{array}$ & $\begin{array}{c}\text { Total fat/[u BW] } \\
{[\mathrm{mg}]^{1}}\end{array}$ & $\begin{array}{c}\text { Fat in egg load/[u BW] } \\
{[\mathrm{mg}]^{2}}\end{array}$ \\
\hline N. sertifer & 34 & $15.8 \pm 2.4^{\mathrm{a}}$ & $71 \pm 12^{\mathrm{a}}$ & $0.245 \pm 0.028^{\mathrm{a}}$ & $0.20 \pm 0.06^{\mathrm{a}}$ & $0.128 \pm 0.047^{\text {****}}$ \\
D. pini & 47 & $32.1 \pm 3.1^{\mathrm{b}}$ & $128 \pm 27^{\mathrm{b}}$ & $0.197 \pm 0.021^{\mathrm{b}}$ & $0.25 \pm 0.03^{\mathrm{b}}$ & $0.146 \pm 0.025^{\text {****}}$ \\
D. similis & 25 & $28.8 \pm 3.0^{\mathrm{c}}$ & $99 \pm 16^{\mathrm{c}}$ & $0.175 \pm 0.021^{\mathrm{c}}$ & $0.24 \pm 0.04^{\mathbf{b}}$ & $0.121 \pm 0.022$ \\
G. frutetorum & 53 & $19.4 \pm 2.6^{\mathrm{d}}$ & $106 \pm 19^{\mathrm{c}}$ & $0.164 \pm 0.027^{\mathrm{d}}$ & $0.28 \pm 0.03^{\mathrm{c}}$ & $0.133 \pm 0.023$ \\
G. pallida & 53 & $14.5 \pm 1.6^{\mathrm{a}}$ & $76 \pm 17^{\mathrm{a}}$ & $0.163 \pm 0.024^{\mathrm{d}}$ & $0.21 \pm 0.04^{\mathrm{a}}$ & $0.090 \pm 0.039^{\text {****}}$ \\
\hline
\end{tabular}

The fat allocation found in the gregarious species G. pallida did not conform to the relationship outlined above. This species distributed significantly more fat to soma than to eggs and did not change this pattern with increase in total fat content. It is possible that the egg-clustering G. pallida might spend more energy selecting favourable oviposition sites than other similar sawfly species. For $N$. sertifer and $D$. pini it has been demonstrated that it is mainly the exposed position of shoots to sunlight (Blümke \& Anderbrant, 1997), the presence of oviposition deterrents (Hilker \& Weitzel, 1991) and needle quality (Björkman et al., 1997) that affects the selection of pine shoots by females. Unfortunately, nothing is known about the oviposition preference of other pine sawflies and therefore it is difficult to judge how fastidious $G$. pallida is in its choice of oviposition sites.

Several comparative studies of pest insects and their nonoutbreak relatives have suggested an association between egg clustering/gregariousness of larvae and outbreak frequency (Hanski, 1987; Wallner, 1987; Larsson et al., 1993). For the species considered in this study, this is only partially true. The pattern of fat allocation to somatic and reproductive tissues seems to be a better predictor: outbreak tendency increases with an increase in the investment of fat in the egg load. In the case of pine sawflies, outbreaks most likely occur when populations are released from top-down control (Hanski \& Parviainen, 1985; Hanski, 1987). When this happens, species with a high potential fecundity may exhibit a rapid population build-up (Hanski, 1987; Wallner, 1987), whereas species with a low fecundity but high power of dispersal may be comparatively restricted in their population increase. This strategy may be more advantageous in non-outbreak situations, as particular mortality risks for the progeny (e. g. attack by egg parasitoids) will be minimized by dispersing spatially or carefully selecting oviposition sites. In fact, there is evidence that densities of some non-outbreak species are at least as high as those of the typical outbreak species during latent periods (Larson \& Tenow, 1980; Simandl, 1989).

Taking into account the small sample size we analysed, the proposed relationship between fat allocation and outbreak tendency in pine sawflies should be regarded as a preliminary conclusion. For instance, the outbreak tendency of species, such as G. pallida, can vary geographically (Pschorn-Walcher, 1982). Moreover, fat allocation may be influenced by diapause or nutrition. We are also aware of the fact that our study was done mainly on insects reared in laboratory cultures and we cannot exclude that the sawflies were subject to an artificial selection. Ideally, fat allocation patterns and other life history traits of field collected specimen from different geographical origins and of different pest status should be compared to determine wether there is a link between resource allocation and population dynamics in pine sawflies.
ACKNOWLEDGEMENTS. We express our thanks to Martti Varama (Finish Forest Research Institute, Finland), Andrej Sierpinski (Forest Research Institute, Poland) and Margarete Feemers (Bayerische Landesanstalt für Wald- und Forstwirtschaft, Germany) for kindly providing sawfly cocoons for establishing cultures. Many thanks to Bettina Hayn for skillful technical assistance and Olle Anderbrant (Lund University, Sweden) for helpful comments on the manuscript. The study was conducted with financial support from the Commission of the European Communities, Agriculture and Fisheries (FAIR) specific RTD programme, CT95-0339, 'Pine sawfly pheromones for sustainable management of European Forests (PHERODIP)'. It does not necessarily reflect the Commission's view and in no way anticipates its future policy in this area.

\section{REFERENCES}

Beenakkers A.M.T. 1969: Carbohydrate and fat as a fuel for insect flight: A comparative study. J. Insect Physiol. 15: 353-361.

BLÜMKe A. \& ANDERBRANT O. 1997: Oviposition pattern and behaviour of the pine sawfly Neodiprion sertifer (Hymenoptera: Diprionidae). Bull. Entomol. Res. 87: 231-238.

BJörkMAN C., LARsson S. \& Bommarco R. 1997: Oviposition preferences in pine sawflies: a trade-off between larval growth and defence against natural enemies. Oikos 79: 45-52.

Codella S.G. \& RafFa K.F. 1995: Contributions of female oviposition patterns and larval behavior to group defence in conifer sawflies (Hymenoptera: Diprionidae). Oecologia 103: 24-33

Crawley M.J. 1993: GLIM for Ecologists. (Methods in Ecology.) Blackwell Scientific Publications, Oxford, UK, 379 pp.

ElLers J. 1996: Fat and eggs: an alternative method to measure the trade-off between survival and reproduction in insect parasitoids. Neth. J. Zool. 46: 227-235.

Escherrch E. 1942: Die Forstinsekten Mitteleuropas. Band V. Paul Parey, Berlin, 746 pp.

HANski I. 1987: Pine sawfly population dynamics: pattern, processes, problems. Oikos 50: 327-335.

Hanski I. \& Parviainen P. 1985: Cocoon predation by small mammals, and pine sawfly population dynamics. Oikos 45 : $125-136$

Herz A. 1997: Zur Effektivität und Struktur der Parasitoidengemeinschaft von Diprion pini (L.) (Hym.; Diprionidae) bei latenten Dichten des Wirtes. $\mathrm{PhD}$ thesis, LudwigMaximilians-Universität München, 193 pp.

Hilker M. \& Weitzel C. 1991: Oviposition deterrence by chemical signals of conspecific larvae in Diprion pini (Hymenoptera: Diprionidae) and Phyllodecta vulgatissima (Coleoptera: Chrysomelidae). Entomol. Gen. 15: 293-301. 
HunTer A.F. 2000: Gregariousness and repellent defences in the survival of phytophagous insects. Oikos 91: 213-224.

LARsSon S., Buörkman C. \& KidD N.A.C. 1993: Outbreaks in Diprionid sawflies: why some species and not others? In Wagner M.R. \& Raffa K.F. (eds): Sawfly Life History Adaptations to Woody Plants. Academic Press, San Diego, pp. 453-483.

Larsson S. \& Tenow O. 1980: Needle-eating insects and grazing dynamics in a mature Scots pine forest in Central Sweden. Ecol. Bull. 32: 269-306.

Lyons L.A. 1962: Th e effect of aggregation on egg and larval survival in Neodiprion swainei Midd. (Hymen.: Diprionidae). Can. Entomol. 94: 49-58.

PapaJ D.R. 2000: Ovarian dynamic and host use. Annu. Rev. Entomol. 48: 423-448.

Prop N. 1960: Protection against birds and parasites in some species of tenthredinid larvae. Arch. Néerl. Zool. 13: $380-447$.
Pschorn-Walcher H. 1982: Symphyta. Diprionidae. In Schwenke W (ed.): Die Forstschädlinge Europas. Vol. 4., Paul Parey Verlag, Hamburg, pp 66-129.

SCHEDL W. 1991: Hymenoptera, Unterordnung Symphyta. In Fischer M. (ed.): Handbuch der Zoologie. Band IV. Arthropoda: Insecta. Walter de Gruyter Verlag, Berlin, New York, $136 \mathrm{pp}$.

SimandL J. 1989: Seasonal changes in the synusia of pine sawflies (Hym., Diprionidae) during their latency. J. Appl. Entomol. 108: 217-226.

WALLNER W.E. 1987: Factors affecting insect population dynamics: differences between outbreak and non-outbreak species. Annu. Rev. Entomol. 32: 317-340.

WheEler D. 1996: The role of nourishment in oogenesis. Annu. Rev. Entomol. 41: 407-431.

Received June 28, 2001; revised September 24, 2001; accepted November 2, 2001 